\title{
Comparative therapeutic efficacy of Gonadotropin Releasing Hormone (GnRH), Human Chorionic Gonadotropin (HCG) analogues and progesterone in non-infectious repeat breeding crossbred cows
}

\author{
Amit Kumar ${ }^{1}$, Sudarshan Kumar ${ }^{1}$, Madhu Shivhare ${ }^{1 *}$, Ranjit Aich ${ }^{2}$ and S. P. Nema ${ }^{1}$ \\ ${ }^{1}$ Department of Veterinary Gynaecology \& Obstetrics, College of Veterinary Science \\ and Animal Husbandry, Mhow, Indore, Madhya Pradesh, India \\ ${ }^{2}$ Department of Veterinary Biochemistry, College of Veterinary Science and Animal \\ Husbandry, Mhow, Indore, Madhya Pradesh, India \\ *Corresponding author
}

\section{Keywords \\ Crossbred cows, repeat insemination, GnRH analogue, HCG, Progesterone \\ Article Info \\ Accepted: \\ 05 January 2020 \\ Available Online: \\ 10 February 2020}

A B S T R A C T

The present study was conducted on 36 crossbred cows with history of repeat insemination at different intervals, randomly categorized in infectious and non-infectious groups on basis of positive or negative reaction to Whiteside test belonging to the Dairy farm of College of Veterinary science and Animal Husbandry, Mhow and clinical cases of progressive farmers brought for artificial insemination to teaching veterinary clinical complex and at the doorstep of farmers in nearby villages. These selected animals divided into 6 groups $\mathrm{GnRH}$ analogue $(\mathrm{Gp}$ I ), GnRH + HCG(Gp II), HCG alone (Gp III), HCG + GnRH (Gp IV), Progesterone (Gp V) and Control Group (Gp VI). He was found higher conception rate in $\mathrm{GnRH}+\mathrm{HCG}(\mathrm{Gp}$ II), $\mathrm{HCG}+\mathrm{HCG}(\mathrm{Gp})$ and Progesterone was 66.66 (4/6), whereas GnRH analogue (Gp I) , HCG alone (Gp II ) and control group was $50 \%$.

\section{Introduction}

Repeat breeding has been defined as failure to conceive from 3 or more regularly spaced services in the absence of detectable abnormalities (Zemjanis, 1980). Oestrus, the most visible phase of the oestrous cycle is characterized by nervousness, bellowing and mounting, stands to be mounted by another cow, reduced feed intake and milk production. During the pre-implantation phase of embryonic development, direct progesterone supplementations and GnRH / hCG injections are the approaches to improve embryonic 
survival in repeat breeder cows (Mann 2002).In dairy cows, luteal insufficiency and lower progesterone concentrations are known as a cause of embryonic mortality and reduce the pregnancy rates during early embryonic development (Howard et al., 2006).

It has been hypothesized that increasing peripheral progesterone concentrations during the diestrus after insemination may improve embryo development and may suppress luteolysis, resulting in reduced embryonic loss.

$\mathrm{GnRH} / \mathrm{hCG}$ injection causes a predictable release of LH hence, administration of GnRH and/or hCG before, during and postinsemination would more precisely synchronize ovulation with estrus, increased the pregnancy rates and decreased the early embryonic deaths (Das et al., 2007)

\section{Materials and Methods}

On the basis of above examination, the animals (non-infectious repeat breeder) were assigned into following groups (Table.1)

\section{Group 1}

Animals in this group $(\mathrm{n}=6)$ were treated with GnRH analogue injection buserelin acetate @ $10 \mu \mathrm{g}(2.5 \mathrm{ml})$ intramuscularly at the time of Artificial Insemination (AI) and it was followed by $12^{\text {th }}$ day after AI.

\section{Group 2}

Animals in this group $(n=6)$ were treated with GnRH analogue injection buserelin acetate @ $10 \mu \mathrm{g}(2.5 \mathrm{ml})$ intramuscularly at the time of AI and injection hCG @ 1500 IU intramuscularly on 12 th day after the AI.

\section{Group 3}

Animals in this group $(\mathrm{n}=6)$ were treated with injection hCG @ 1500 IU intramuscularly at the time of AI followed by $12^{\text {th }}$ day after the AI.

Table.1 Grouping of animals

\begin{tabular}{|l|l|l|l|}
\hline \multicolumn{1}{|c|}{ Groups } & No. of Animals & Type of Animal & \multicolumn{1}{c|}{ Treatment given } \\
\hline Group 1 & 6 & Repeat breeder & GnRH at AI $+12^{\text {th }}$ day \\
\hline Group 2 & 6 & Repeat breeder & GnRH at AI $+\mathrm{hCG}$ on $12^{\text {th }}$ day \\
\hline Group 3 & 6 & Repeat breeder & hCG at AI $+12^{\text {th }}$ day \\
\hline Group 4 & 6 & Repeat breeder & hCG at AI + GnRH on $12^{\text {th }}$ day \\
\hline Group 5 & 6 & Repeat breeder & $\mathrm{P}_{4}$ on $4^{\text {th }}$ day after AI \\
\hline $\begin{array}{l}\text { Group 6 } \\
\text { (Control } \\
\text { group) }\end{array}$ & 6 & Repeat breeder & Normal saline at AI $+12^{\text {th }}$ day \\
\hline
\end{tabular}




\section{Group 4}

Animals in this group ( $\mathrm{n}=6)$ were treated with injection hCG @ 1500 IU intramuscularly at the time of $\mathrm{AI}$ and $\mathrm{GnRH}$ analogue injection buserelin acetate @ $10 \mathrm{mcg}(2.5 \mathrm{ml})$ intramuscularly on 12th day after the AI.

\section{Group 5}

Animals in this group $(\mathrm{n}=6)$ were treated with injection hydroxyl progesterone $500 \mathrm{mg} \mathrm{I} / \mathrm{M}$ on $4^{\text {th }}$ day of estrum after first insemination.

\section{Group 6 (Control group)}

Animals in this group $(\mathrm{n}=6)$ were noninfectious repeat breeder crossbred cows and treated with injection normal saline $(2 \mathrm{ml})$ intramuscularly at the time of $\mathrm{AI}$ and on $12^{\text {th }}$ day after AI as placebo.

\section{Pregnancy diagnosis}

Cows were examined per-rectum at 45 to 60 days post- AI to confirm pregnancy.

\section{Conception rate}

Therapeutic efficacy of drugs was judged on the basis of per rectal examination for pregnancy diagnosis at day 45 post treatment.

\section{Statistical analysis}

Data analysis was done as per the standard statistical method by application of Factorial Completely Randomized Design (Snedecor and Cochran ,1994).

\section{Results and Discussion}

Thirty Six crossbred cows showing negative reaction to Whiteside test were subjected to different hormonal therapeutic protocols. Before initiating hormonal treatment, owners of the animals were supplied with multi mineral bolus for PO use, one bolus on alternate day for four times. The selected repeat breeding crossbred cows with average body condition score (BCS) of 2.75 to 3.50 , without visible and palpable genital abnormalities were treated once with SC injection of $10 \mathrm{ml}$ Ivermectin and IM injection of $1.0 \mathrm{~g}$ Enrofloxacin to check invisible genital infection and also with IM injection of $10 \mathrm{ml}$ inorganic phosphorus and multivitamins AD3E.

In $\mathrm{GnRH}+\mathrm{GnRH}$ analogue injection treatment protocol, six non-infectious repeat breeder crossbred cows, each were administered with IM Inj. of Buserelin acetate $10 \mu \mathrm{g}(2.5 \mathrm{ml})$ on the day of diagnosis/ treatment $\left(0^{\text {th }}\right.$ day of estrus) followed by second inj. of Buserelin acetate $10 \mu \mathrm{g}(2.5 \mathrm{ml})$ IM on $12^{\text {th }}$ day post- AI.

The conception rate in $\mathrm{GnRH}+\mathrm{GnRH}$ analogue treated non-infectious repeat breeder cross bred cows were found to be $16.66(1 / 6)$ per cent at $1^{\text {st }}$ oestrus, $33.33(2 / 6)$ per cent in $2^{\text {nd }}$ oestrus and $00.00(0 / 6)$ per cent in $3^{\text {rd }}$ oestrus, with an overall pregnancy rate of $50.00(3 / 6)$ per cent.

The present findings approximates with the observation reported by Drew and Peters (1992) , who reported 12 per cent higher pregnancy rate in $\mathrm{GnRH}$ treated cows on day 12 after insemination than in control animals. An overall enhancement in conception rate of 83.33 as against 33.33 per cent in control groups has been reported in cows through GnRH therapy irrespective of days of administration (Dodamani et al., 2010).

The present results are in agreement with the finding that the use of $\mathrm{GnRH}$ at the time of AI increases conception rate in dairy cows (Parmar et al., 2013 and Jaswal and Singh, 2013). Similarly, Lopez-Gaitus et al., 2006 
reported that $\mathrm{GnRH}$ administration during AI and after 12 days increased the pregnancy rates.

In $\mathrm{GnRH}$ analogue + hCG injection treatment protocol, six non-infectious repeat breeder crossbred cows each were then administered with IM Inj. of Buserelin acetate $10 \mu \mathrm{g}(2.5$ $\mathrm{ml})$ on the day of diagnosis/ treatment $\left(0^{\text {th }}\right.$ day of estrus) followed by second IM Inj. of hCG, $1500 \mathrm{IU}$ on $12^{\text {th }}$ day post- AI.

The conception rate in $\mathrm{GnRH}$ analogue + hCG injection treated non-infectious repeat breeder cross bred cows were found to be $33.33(2 / 6)$ per cent at $1^{\text {st }}$ oestrus, $16.66(1 / 6)$ per cent in $2^{\text {nd }}$ oestrus and $16.66(1 / 6)$ per cent in $3^{\text {rd }}$ oestrus, with an overall pregnancy rate of $66.66(4 / 6)$ per cent.

Administration of $\mathrm{GnRH}$ on day 0 post-AI might have induced luteinisation and /or ovulation of dominant follicle of first follicular wave which successfully increased concentrations of progesterone during midluteal phase in lactating dairy cows (Beltran and Vasconcelos, 2008) and minimized the luteolytic cascade by endometrial cells during the period of maternal recognition of pregnancy, which favours pregnancy maintenance (Kerbler et al., 1997; Mann et al., 2001) and Nayak (2015).

In hCG injection + hCG injection treatment protocol, six non-infectious repeat breeder crossbred cows each were then administered with IM Inj. of hCG, 1500 IU on the day of diagnosis/ treatment ( $0^{\text {th }}$ day of oestrus) followed by second IM Inj. of hCG, 1500 IU on $12^{\text {th }}$ day post- AI.

The conception rate in hCG injection + hCG injection treated non-infectious repeat breeder cross bred cows were found to be 16.66(1/6) per cent at $1^{\text {st }}$ oestrus, $33.33(2 / 6)$ per cent in $2^{\text {nd }}$ oestrus and $16.66(1 / 6)$ per cent in $3^{\text {rd }}$ oestrus, with an overall pregnancy rate of 66.66 (4/6) per cent. The conception rate obtained with hCG treatment group was higher than in control group. The present findings are in agreement Senthil et al., (2014). Although, Parmar et al.(2013) and Mathew et al., (2013) reported higher conception rate in hCG treated repeat breeder cows but the present findings differed from Paksoy and Kalkan, 2010, who concluded that hCG had no effect on conception rate if injected at the time of AI.

In hCG injection + GnRH analogue treatment protocol, six non-infectious repeat breeder crossbred cows each were then administered with IM Inj. of hCG, $1500 \mathrm{IU}$ on the day of diagnosis/ treatment $\left(0^{\text {th }}\right.$ day of oestrus $)$ followed by second inj. of Buserelin acetate $10 \mu \mathrm{g}(2.5 \mathrm{ml}) \mathrm{IM}$ on $12^{\text {th }}$ day post- AI.

The conception rate in hCG injection $+\mathrm{GnRH}$ analogue treated non-infectious repeat breeder cross bred cows were found to be 16.66 (1/6) per cent at $1^{\text {st }}$ oestrus, $16.66(1 / 6)$ per cent in $2^{\text {nd }}$ oestrus and $16.66(1 / 6)$ per cent in $3^{\text {rd }}$ oestrus, with an overall pregnancy rate of $50.00(3 / 6)$ per cent.

HCG (Human chorionic gonadotropin) injection causes a predictable release of luteotrophic hormone ( $\mathrm{LH})$ hence, administration of $\mathrm{hCG}$ before, during and post-insemination would more precisely synchronize ovulation with estrus, increased the pregnancy rates and decreased the early embryonic deaths (Das et al., 2007).

The improvement in the conception rate with the use of GnRH during luteal phase has been attributed to the fact that GnRH on day 12 induces ovulation of the first wave dominant follicle (FWDF), thus forming an accessory $\mathrm{CL}$ and enhancing progesterone production early in the cycle. 
This increase in progesterone secretion caused by GnRH may facilitate embryonic development (Mann and Lamming, 1999). In Progesterone injection treatment protocol, six non-infectious repeat breeding crossbred cows were treated with IM inj. of $500 \mathrm{mg}$ of hydroxyl-progesterone on day $4^{\text {th }}$ day of insemination.

The conception rate in Progesterone injection treated non-infectious repeat breeder cross bred cows were found to be $33.33(2 / 6)$ per cent at $1^{\text {st }}$ oestrus, $16.66(1 / 6)$ per cent in $2^{\text {nd }}$ oestrus and $16.66(1 / 6)$ per cent in $3^{\text {rd }}$ oestrus, respectively, in the treatment cycle itself and post-treatment I and II cycles. The pooled conception rate obtained in treated crossbred cows was $66.66(4 / 6)$ per cent.

The present finding of 70.00 per cent overall conception rate obtained in repeat breeder cows administered with $500 \mathrm{mg}$ progesterone IM on 5thday post-AI was closely in agreement with the previous reports of Srivastava and Kharche (2001); who obtained 65.21 per cent conception rate, respectively. The conception rate recorded in the present study were higher than the conception rate of $44.00,30.00$ and 30.88 per cent recorded by Stevenson and Mee(1991), Singh and Nanda(2007).

In injection normal saline + injection normal saline as Placebo treatment protocol, six noninfectious repeat breeder crossbred cows, each were administered with IM Inj. of normal saline $(2 \mathrm{ml})$ on the day of diagnosis/ treatment $\left(0^{\text {th }}\right.$ day of oestrus $)$ followed by second inj. of normal saline (2ml) IM as Placebo on $12^{\text {th }}$ day post- AI.

The conception rate in injection normal saline + injection normal saline as Placebo treated non-infectious repeat breeder cross bred cows were found to be $16.66(1 / 6)$ per cent at $1^{\text {st }}$ oestrus, $16.66(1 / 6)$ per cent in $2^{\text {nd }}$ oestrus and
$16.66(1 / 6)$ per cent in $3^{\text {rd }}$ oestrus, with an overall pregnancy rate of $50.00(3 / 6)$ per cent. In control group cows, the overall conception rate obtained was 50 per cent which closely corroborates with the findings of Bhattacharya and Hafiz(2009);Derar et al.(2012) and Patel et al.(2014a).

In contrast, relatively lower overall conception rate obtained by others between 40 to 60 per cent include, Singh et al., (2002) However, much lower conception rate below 40 per cent were also observed by others include Patel et al., (2005b); Singh and Nanda ( 2007); Kadarbhai et al.(2012)and Biradare et al.(2014).

\section{References}

Beltran, M.P. and Vasconcelos, J.L.M. (2008). Conception rate in Holstein cows treated with GnRH or hCG on the fifth day post artificial insemination during summer. Brazilian Journal of Veterinary and Animal Science, 60(3): 580-586.

Bhattacharyya, H.K. and Hafiz, A. (2009). Treatment of delayed ovulation in dairy cattle. Indian Journal of Animal Research, 43(3): 209-210.

Biradar, S., Tandle, M.K., Haribabu, Y., Usturge, S.M., Patil, N.A. and Suranagi, M.D. (2014). Study on efficacy of cosynch and ovsynch protocol on fertility in repeat breeder buffaloes. Indian Journal of Advances in Plant Research, 1(5): 1-3.

Das, P.K., Deka, K.C., Biswas, R.K. and Goswami, J. (2007). Ovulatory disturbance and its therapeutic approach in repeat breeding crossbred cattle. Indian Journal of Animal Science, 77: 45-47.

Derar, R., Hussein, H.A., Fahmy, S., EISherry, T.M. and Megahed, G. (2012). The effect of parity on the efficacy of 
ovulation synchronization (Ovsynch) protocol in buffalo (Bubalus bubalis). Animal Reproduction, 9(1): 38-43.

Howard, M.J., Manzo, R., Dalton, C.J., Frago, F., Ahmadzadeh, (2006) A.: Conception rates and serum progesterone concentration in dairy cattle administered gonadotropin releasing hormone 5 days after artificial insemination. Animal Reproduction Science, 9: 224-233

Kadarbhai, A.M., Ghaisas, A.S., Gulavane, S.U., Bakshi, S.A., Rangnekar, M.N. and Chaudhari, R.J. (2012). Efficacy of prostaglandins in postpartum lactating dairy crossbred cows on days open. In: State symposium on "Recent advances in reproductive technologies and obstetrical procedures for augmenting fertility in farm animals, Panchgani, 5th February, pp 136.

Kerbler, T.L., Buhr, M.M. and Jordan, L.T. (1997). Relationship between maternal plasma progesterone concentration and interferon-tau synthesis by the conceptus in cattle. Theriogenology, 47:703-714.

Mann, G.E. (2002). Corpus luteum function and early embryonic death in the bovine. 22. World Buiatrics Congress. Hannover, pp 300-306.

Mann, G.E. and Lamming, G.E. (1999). The influence of progesterone during early pregnancy in cattle. Reproduction in Domestic Animals, 34: 269-274.

Mann, G.E., Payne, J.H. and Lammining, G.E. (2001). Hormonal regulation of oxytocin- induced prostaglandin F2 $\alpha$ secretion by the bovine and ovine uterus in vivo. Domestic Animal Endocrinology, 21: 127-141.

Mathew, R. Aravinda, M., Ghosh, K.N., Kurien, M.O., and Harshan, H.M. (2013). Comparison of Human Placental Extract, hCG and GnRH Analogue on Fertility of Repeat
Breeding Cattle. Indian Veterinary Journal, 90(4): 57-59.

Nayak, J.K (2015). Studies on effect of postinsemination $\mathrm{GnRH}$ administration during early and mid luteal phase on fertility in Sahiwal cows. M.V.Sc. Thesis (Veterinary Gynaecology \& Obstetrics). Chhattisgarh Kamdhenu Viahwavidyalaya, Durg.

Paksoy Z and Kalakan C (2010). The Effects of GnRH and hCG Used During and After Artificial Insemination on Blood Serum Progesterone Levels and Pregnancy Rate in Cows. Kafkas Universitesi Veteriner Fakultesi Dergisi, 16 (3): 371-375.

Parmar, S.V., Patel, J.A. and Dhami A.J. (2013). Effect of hormone therapy on fertility and plasma minerals profile in repeat breeding Gir cows. Indian Journal of Field Veterinarians, 8(4): 1825.

Patel, J.A., Dhami, A.J., Kavani, F.S. and Sarvaiya, N.P. (2005b). Effect of hormonal therapies at breeding on plasma progesterone profile and fertility in repeat breeding Holstein Friesian cows. International Journal of Cow Science, 1(1): 52-59.

Patel, K.R., Dhami, A.J., Hadiya, K.K., Savalia, K.K., Killedar, A. and Patel, S.B. (2014). Effect of mid-cycle PGF2 $\alpha$ and GnRH at AI on conception rates, plasma progesterone and biochemical profile in repeat breeding crossbred cows. Indian Journal of Field Veterinarians, 9(3): 5-11.

Senthil, A.K., SriBalaji, N. and Shanmugasundram, A. (2014). Four different therapeutic regimens for management of repeat breeder dairy cattle in theni district of Tamilnadu. International Journal of Advanced Veterinary Science and Technology, 3(1): 131-133.

Singh, J. and Nanda, A.S. (2007). 
Interventions for improving the fertility of crossbred cows subjected to artificial insemination under field conditions. In: Improving the Reproductive Management of Dairy Cattle subjected to Artificial Insemination, pp 47-55.

Singh, Madhumeet, Vashishta, N.K., Sood. P. and Katoch, A. (2002). Effect of progesterone supplementation on conception in normal and repeat breeder cows. Indian Veterinary Journal, 79(1): 92-93.

Snedecor, G.W. and Cochran, W.G. (1994). Statistical Methods, 7th Edn., Oxford and IBH Publishing Co., New Delhi, pp 312-317.

Srivastava, S.K. and Kharche, S.D. (2001). Effect of progesterone supplementation on conception rate in repeat breeder cattle. Indian Journal of Animal Reproduction, 22(1): 35-37.

Zemjanis, R. (1980). Repeat breeding or conception failure in cattle. In: D.A. Morrow (ed.) Current Therapy in Theriogenology, W.B. Saunders, Publishing Co., Philadelphia, pp 205213.

\section{How to cite this article:}

Amit Kumar, Sudarshan Kumar, Madhu Shivhare, Ranjit Aich and S. P. Nema. 2020. Comparative therapeutic efficacy of Gonadotropin Releasing Hormone (GnRH), Human Chorionic Gonadotropin (HCG) analogues and progesterone in non-infectious repeat breeding crossbred cows. Int.J.Curr.Microbiol.App.Sci. 9(02): 24-30.

doi: https://doi.org/10.20546/ijcmas.2020.902.005 